\title{
OLIVE LEAF EXTRACTS APPLICATION FOR SHELF LIFE EXTENSION OF VACUUM-PACKED FRIGATE MACKEREL (AUXIS THAZARD) FILLETS
}

\author{
Talal Lahreche ${ }^{1 凶}$, Mustafa Durmus², Elif Tugce Aksun Tümerkan ${ }^{3,4}$, Taha-Mossadak Hamdi ${ }^{1}$, \\ Fatih Özogul ${ }^{2}$ \\ ${ }^{1}$ Laboratory of Food Hygiene and Quality Insurance System (HASAQ), High National Veterinary School, Issad \\ Abbes Avenue, Oued Smar, Algiers, Algeria. \\ ${ }^{2}$ Department of Seafood Processing Technology, Faculty of Fisheries, Cukurova University, Adana, Turkey. \\ ${ }^{3}$ Department of Bioscience, University of Exeter, Cornwall, United Kingdom. \\ ${ }^{4}$ Department of Technical Research and Quality Control, General Directorate of State Hydraulic Works (DSI), \\ Ankara, Turkey. \\ $\triangle_{t . l a h r e c h e @ e t u d . e n s v . d z}$ \\ https://doi.org/10.34302/crpjfst/2020.12.4.8 \\ Article history: $\quad$ ABSTRACT \\ Received: \\ 15 March 2020 \\ Accepted: \\ 21 October 2020 \\ The current study was aimed at investigating the impact of olive leaf \\ extracts (OLE) on the quality parameters of white and dark muscles from \\ fillets of frigate mackerel (Auxis thazard) stored under vacuum pack (VP) \\ at a refrigerated temperature $\left(3 \pm 1^{\circ} \mathrm{C}\right)$. The sensory assessment indicated \\ Keywords: \\ Olive leaf extract; \\ Fish muscles; \\ Quality parameters; \\ Vacuum packaging; \\ Refrigerated storage. \\ that both muscle types of frigate mackerel had 12 days of shelf-life, while \\ the application of OLE extended the shelf-life by 3 and 6 days in the white \\ and dark muscles, respectively. However, total volatile base-nitrogen \\ exhibited a longer shelf-life in all samples, while thiobarbituric acid values \\ showed shorter shelf-life for control samples. OLE application initiated the \\ lipid peroxidation in white muscle at an early stage of storage and \\ improved the microbiological quality of both muscles by reducing bacterial \\ growth. An assessment of various texture related parameters indicated that \\ VP alone could not enhance the textural quality in both muscles, while \\ OLE improved adhesiveness and circumvented the softening of both \\ frigate mackerel muscles.
}

\section{Introduction}

Fish has become an important source of human nutrition and is highly recommended by dieticians due to high-quality protein value and fatty acids profile. However, fish is a highly variable and perishable food due to the neutral $\mathrm{pH}$, high water activity and simultaneous presence of microbial and enzymatic activities (Jeyasekaran et al., 2006). Traditionally, fish are preserved at low temperature to maintain quality. However, the inconvenience of dehydration, textural hardness, nutrient loss and reduced extractability of protein are some of the drawbacks associated with cold storage (Putro, 1989). During low-temperature storage, the lipid peroxidation takes place, and once it starts, it cannot be reverted and gets intensified when fish is filleted due to the increased surface area that comes into contact with oxygen. Therefore, it is necessary to develop efficient methods for preservation of seafood to avoid deterioration and maintain the fish quality in term of original color, texture, and flavor for a long period (Jeyasekaran et al., 2006).

Vacuum packaging (VP) is one of the most widely used preserving methods that provide an oxygen-free environment. The preservative effect of VP is mainly limited to the prevention of lipid peroxidation and the growth of most spoiling microorganisms. However, even under such conditions, the growth of psychrotrophic 
anaerobic or microaerophilic pathogens occurs, which is of great concern in terms of food safety and human health. The growth of the dominant bacteria associated with the fish spoilage, e.g., psychrotrophic lactic acid bacteria, results in unpleasant odors and a viscous appearance (Coma, 2008).

The addition of low levels of preservatives (natural or synthetic) with packaging is a desirable method of food preservation when combined with low temperatures; it could noticeably prolong the shelf-life of fish. Natural preservatives, obtained from plant products, are mainly used alone or in combination with other methods such as VP and low temperatures (Skandamis and Nychas, 2001) to enhance the sensory quality and extend the shelf-life of seafood and their derivative products. Such natural preservatives exert their effect through antimicrobial and antioxidant activities (Burt, 2004).

One of the most commonly used plants is olive (Olea europaea L.) and is widely cultivated throughout the Mediterranean region. Olive oil is the main product that is widely used in food, cosmetic, and therapeutic industries. In addition, the therapeutic properties of the olive plants are attributed to the antiseptic virtues of its leaves. Recently, scientific interest has grown in olive leaf extract (OLE) as a natural compound endowed with antimicrobial, antioxidant, anti-inflammatory, antihypertensive and other health benefits for human (Delgado-Adámez et al., 2016). The natural antioxidant and antimicrobial properties of OLE may be explored to extend the shelflife of fresh vacuum packed fish. There are several reports on the effect of the combination of natural preservatives and VP on the shelf life of different marine species (Kenar et al. 2010; Ucak et al. 2011; Houicher et al., 2013; Viji et al., 2016; Chaves et al., 2017; Lahreche et al., 2019; El-Sohaimy et al., 2019). However, to the best of our knowledge, no study has reported the differences between the combined effect of natural olive leaf extract and VP on the quality parameters of white and dark muscles of fish so far. Therefore, the present study was aimed to evaluate sensory, microbiological, chemical, and textural parameters of the white and dark muscle of frigate mackerel (Auxis thazard) fillets by applying OLE as a natural preservative followed by vacuum packaging and storage at a refrigerated temperature.

\section{Materials and methods}

\subsection{Plants extract preparation}

Fresh Olive leafs (Olea europaea L.) were dried in the dark at ambient temperature and finely ground. Extraction was accomplished in accordance with the method reported by Kenar et al. (2010) with slight modifications using absolute ethanol $96 \%(\mathrm{v} / \mathrm{v})$. Ethanol from the filtrate was completely evaporated using a rotary evaporator (Heidolph Rotating Evaporator, VV2000, Schwabach, Germany), and the ethanol-free filtrate was kept in the dark at $-18^{\circ} \mathrm{C}$ till usage. Before using, the extract was treated by UV-light $(30 \mathrm{~W}, 50 \mathrm{~cm}$ irradiation distance) using a laminar flow cabinet (Telstar Bio-II-A, Telstar, Madrid, Spain) for $30 \mathrm{~min}$ to eliminate any existing microflora.

\subsection{Fish sample preparation}

Frigate mackerel (Auxis thazard) was caught from Mediterranean Sea; Turkey and was stored in ice for approximately 6 hours post-capture. On arrival at the laboratory, fish were immediately gutted, beheaded, filleted without skin separation and rinsed with tap water. The average weight, length, width and thick of the obtained fish fillets were $151.53 \pm 26.88 \mathrm{~g}, \quad 20.31 \pm 1.15 \mathrm{~cm}, \quad 8.01 \pm 0.51 \mathrm{~cm}$ and $1.46 \pm 0.21 \mathrm{~cm}$, respectively $(n=10)$. After that, fillets were randomly allocated into two lots. One lot kept as control (untreated) and the second lot was dipped in a sterile distilled water containing $0.5 \%$ of sterilized OLE for 5 min (treated). All lots were vacuum packaged in bags of polyamide film (Polinas, Manisa, Turkey) with $90 \mu \mathrm{m}$ of film thickness, 8.5 $\mathrm{g} / \mathrm{m}^{2} / 24 \mathrm{~h}$ of water permeability and 160 $\mathrm{cm}^{3} / \mathrm{m}^{2} / 24 \mathrm{~h}$ oxygen permeability. All groups were stored as intact fillet at $3 \pm 1^{\circ} \mathrm{C}$. Sensory 
characteristics, chemical changes, microbial spoilage and texture analysis were assessed, in triplicate, on days $0,4,8,12,15$, and 18 in separated white and dark muscles obtained from the same fillet.

\subsection{Chemical analysis and $\mathbf{p H}$}

$\mathrm{pH}$ values were recorded in accordance with Woyewoda et al. (1986) method. Total volatile basic nitrogen (TVB-N) content was accomplished by using the Antonocopoulos (1973) method. Peroxide value (PV) was done by AOCS (1994) method. Thiobarbituric acid reactive substances value (TBARs) was achieved in line with Tarladgis et al. (1960) method. Free fatty acid analysis (FFA) was carried out by the AOCS (1994) procedure.

\subsection{Microbiological analysis}

Preparation of test samples from fish muscles, initial suspension and serial decimal dilutions for microbiological analysis were prepared using sterile quarter-strength Ringer's solution (Fluka; Sigma Aldrich, Sweden) (ISO., 2017). Aliquot of $0.1 \mathrm{ml}$ from each dilution was spread gently onto the surface of the dry media (ISO., 2013; ISO., 2001). The enumeration of aerobic mesophilic and psychrophilic bacteria was performed in plate count agar (Fluka 70152; Steinheim, Switzerland) after incubation for $72 \mathrm{~h}$ at $30^{\circ} \mathrm{C}$ (ISO., 2013) and for 10 days at $6.5^{\circ} \mathrm{C}$ (ISO., 2001), respectively. All analysis was performed in triplicate and was taken from each of dark and white muscles of each of two different groups. All microbiological data are expressed as a logarithm of colony forming units per gram of sample.

\subsection{Sensory analysis}

Quality Index Method (QIM) established by Ariyawansa et al. (2003) for filleted fish was used with some modifications for sensory assessment. The scheme contained five quality parameters (e.g. surface and skin appearance, color, texture and odor of fillet, and plant extract odor). Generally, the scheme had a score system for each of parameters of 4 demerit points ranged from 0 (best quality) to a maximum of 3 (poorer quality). The total sum of demerit point was 15 . The Panel, consisting of six trained evaluators, inspected fillets and recorded the appropriate demerit point for each of parameters and then the scores of all parameters are summed to give an overall demerit score, so-called quality index score. The panel was requested to state whether the fish were acceptable or not for the determination of the shelf-life of frigate mackerel fillets.

Sensory evaluations of cooked frigate mackerel were assessed following to the same method of Ariyawansa et al. (2003) without modification. Fish fillets were cooked in a microwave for $4 \mathrm{~min}(700 \mathrm{~W})$ and then served hot. Panelists scored for odor and flavor, using a torry score with eight-point hedonic scale (3, poorest quality to 10 , best quality). The rejection threshold set at $\leq 6$.

\subsection{Texture Profile Analysis (TPA)}

Texture profile analysis (TPA) was done in line with the modified procedure of Liu et al. (2014) in triplicate using a texture analyzer TAXT Plus equipped with a load cell of $50 \mathrm{~N}$ and the software was Texture Expert, v1.20 (Stable Micro Systems Ltd, Godalming, Surrey, UK). Before analysis, samples having a length, height and thickness: $35 \mathrm{~mm}, 20 \mathrm{~mm}$ and $10 \mathrm{~mm}$, respectively were prepared from each of white and dark muscles. A flat-ended cylinder $(\mathrm{P} / 36 \mathrm{R})$ with a diameter of $35 \mathrm{~mm}$ was used at a constant speed of $1 \mathrm{~mm} / \mathrm{s}$ until it accomplished $50 \%$ of the sample thickness. After that, the force was decreased and the sample was able to rebound for 10 seconds leaving the cylinder just touching the surface, then the cylinder was pressed on the sample a second time. From the resulting force/deformation graphs, five textural parameters including hardness, springiness, adhesiveness, resilience and chewiness were estimated.

\subsection{Statistical analysis}

All mean values and standard deviations were determined from triplicate data obtained 
for each of muscle type from each lot. Analysis of variance (ANOVA) was applied using the Statistical Package for Social Science (SPSS 19.0 for windows, SPSS Inc., Chicago, IL, USA) followed by Duncan's Multiple Range Tests at $\mathrm{P}$ value of $<0.05$ were carried out to conclude the significant differences.

\section{Results and discussions}

\subsection{Chemical analysis and $\mathbf{p H}$}

Table 1 summarizes the variations in $\mathrm{pH}$ and chemical parameters on each sampling day. The initial $\mathrm{pH}$ of dark muscles was significantly higher $(\mathrm{p}<0.05)$ than that of white muscles. Similar values were also found by Junsi et al. (2012) for dark muscle of skipjack tuna (Katsuwonus pelamis). On the contrary, Chaijan et al. (2013) reported that the initial $\mathrm{pH}$ of the same species was higher in white muscles than the dark ones, indicating that $\mathrm{pH}$ may vary not only among fish species but also within the same species, which might be due to the several factors including season, harvesting procedures, biological condition, and methods of killing (Mazorra-Manzano et al., 2000). Throughout the experiment, $\mathrm{pH}$ values of dark muscles were significantly higher $(p<0.05)$ than those of white muscles, irrespective of treatment. This may happen due to the breakdown of glycogen to lactic acid that must have occurred in white muscle due to the intense activity/stress during capture resulting in lowered $\mathrm{pH}$ (Modigh and Tota, 1975). In all experiment, changes in $\mathrm{pH}$ showed the same tendency in both muscles during the storage. In the treated samples, $\mathrm{pH}$ reached to the maximum level in both muscles only on the $4^{\text {th }}$ day of storage. The increase in $\mathrm{pH}$ may be caused by the accumulation of alkaline compounds such as ammonia and trimethylamine (Ruiz-capillas and Moral, 2005) and/or biogenic amines mainly produced by fish spoiling bacteria (Krízek et al., 2004). The decrease in $\mathrm{pH}$ may also be attributed to the anaerobic glycogen decomposition occurring in fish (Song et al., 2011). No differences $(p>0.05)$ between the treatments were observed in dark muscles. At the end of storage, $\mathrm{pH}$ in all groups declined significantly $(\mathrm{p}<0.05)$ in both muscle types, probably due to the growth of lactic acid bacteria (Li et al., 2016). These results inferred that the application of OLE along with VP could affect the $\mathrm{pH}$ value of frigate mackerel muscles; however, the $\mathrm{pH}$ value should not be considered as an important index to determine the freshness of the fish.

The TVB-N values were increased with storage time and generated by the microbial spoilage and enzymatic activity; however, this rise does not reveal the mode of spoilage and depend greatly on the analytical method (Song et al., 2011; Mazorra-Manzano et al., 2000). Initially, TVB-N values were significantly lower $(p<0.05)$ in white muscles than dark muscles and are in line with the findings by Liu et al. (2014). This might be due to the fact that dark muscle is generally rich in vitamin and minerals, and hence a good source of nutrients for microbial growth (Wendakoon et al., 1990). In our study, TVB-N values increased with time in both muscle types for all packaged samples followed by a decline, which indicates a reduction in bacterial activity at the end of storage. The TVB-N data marked significant differences $(p<0.05)$ between both muscle types throughout the storage time for control samples and until 12 days of storage for the treated samples. Over the storage period, TVB$\mathrm{N}$ values of control samples were significantly lower $(p<0.05)$ in white muscle than dark muscle, indicating that white muscle spoiled slowly than dark muscle. However, the application of OLE showed a protective effect on fish fillets and yielded the lowest $(p<0.05)$ TVB-N values in both muscles than the control. The noticeable reduction in TVB-N in the treated samples may be associated with the effect of the combination of VP with the antibacterial properties of the phenolic compounds present in OLE such us oleuropein, verbascoside, and hydroxytyrosol (BenaventeGarcía et al., 2000). Throughout the investigation, only the control sample exceeded the acceptability limit (30 mg TVB-N/100g: Liu et al., 2014) on the 15 days reaching the TVB-N of 30.65 and $30.11 \mathrm{mg} / 100 \mathrm{~g}$ for the 
white and dark muscles, respectively. In contrast, TVB-N values of both muscles in the treated samples were below this limit until the end of the storage and carried lower values than the control samples. Thus, TVB-N may potentially be a suitable index for assessing the spoilage of filleted frigate mackerel stored at a refrigerated temperature under VP conditions.

Table 1. Effect of OLE on $\mathrm{pH}$, TVB-N (mg/100g of sample), PV (mEq/kg of fat), TBA (mg malonaldehyde/kg of the sample) and FFA (oleic acid \%) in white and dark muscles of vacuum-packed frigate mackerel stored at a refrigerated temperature $\left(3 \pm 1^{\circ} \mathrm{C}\right)$.

\begin{tabular}{|c|c|c|c|c|c|c|c|}
\hline \multicolumn{2}{|c|}{ Storage time (days) } & \multicolumn{2}{|l|}{$\mathbf{0}$} & \multicolumn{2}{|l|}{4} & \multicolumn{2}{|l|}{8} \\
\hline Parameters & Samples & W & D & $\mathbf{W}$ & D & $\mathbf{W}$ & D \\
\hline pH & $\begin{array}{l}\text { Control } \\
\text { OLE }\end{array}$ & $5.69 \pm 0.01^{\mathrm{Y}}$ & $5.77 \pm 0.02^{\mathrm{X}}$ & $\begin{array}{l}5.73 \pm 0.04^{\mathrm{a}, \mathrm{Y}} \\
5.82 \pm 0.09^{\mathrm{a}, \mathrm{Y}}\end{array}$ & $\begin{array}{l}5.89 \pm 0.06^{\mathrm{a}, \mathrm{X}} \\
5.95 \pm 0.07^{\mathrm{a}, \mathrm{X}}\end{array}$ & $\begin{array}{l}5.85 \pm 0.04^{\mathrm{a}, \mathrm{X}} \\
5.77 \pm 0.05^{\mathrm{b}, \mathrm{Y}}\end{array}$ & $\begin{array}{l}5.89 \pm 0.03^{\mathrm{a}, \mathrm{X}} \\
5.89 \pm 0.03^{\mathrm{a}, \mathrm{X}}\end{array}$ \\
\hline TVB-N & $\begin{array}{l}\text { Control } \\
\text { OLE }\end{array}$ & $12.82 \pm 0.41^{\mathrm{Y}}$ & $17.21 \pm 0.84^{\mathrm{X}}$ & $\begin{array}{l}18.94 \pm 0.70^{\mathrm{a}, \mathrm{Y}} \\
17.24 \pm 0.63^{\mathrm{a}, \mathrm{Y}}\end{array}$ & $\begin{array}{l}28.29 \pm 0.88^{\mathrm{a}, \mathrm{X}} \\
20.36 \pm 1.72^{\mathrm{b}, \mathrm{X}}\end{array}$ & $\begin{array}{l}21.41 \pm 0.73^{\mathrm{a}, \mathrm{Y}} \\
15.70 \pm 0.70^{\mathrm{b}, \mathrm{Y}}\end{array}$ & $\begin{array}{l}22.96 \pm 0.63^{\mathrm{a}, \mathrm{X}} \\
17.39 \pm 0.77^{\mathrm{b}, \mathrm{X}}\end{array}$ \\
\hline PV & $\begin{array}{l}\text { Control } \\
\text { OLE }\end{array}$ & $2.61 \pm 0.23^{\mathrm{X}}$ & $1.45 \pm 0.20^{\mathrm{Y}}$ & $\begin{array}{l}3.83 \pm 0.04^{\mathrm{b}, \mathrm{X}} \\
8.12 \pm 1.86^{\mathrm{a}, \mathrm{X}}\end{array}$ & $\begin{array}{l}1.88 \pm 0.07^{\mathrm{a}, Y} \\
1.70 \pm 0.08^{\mathrm{a}, \mathrm{Y}}\end{array}$ & $\begin{array}{l}6.33 \pm 1.15^{\mathrm{a}, \mathrm{X}} \\
2.34 \pm 0.49^{\mathrm{b}, \mathrm{X}}\end{array}$ & $\begin{array}{l}0.99 \pm 0.02^{\mathrm{b}, \mathrm{Y}} \\
1.22 \pm 0.10^{\mathrm{a}, \mathrm{Y}}\end{array}$ \\
\hline TBA & $\begin{array}{l}\text { Control } \\
\text { OLE }\end{array}$ & $0.56 \pm 0.01^{\mathrm{Y}}$ & $0.64 \pm 0.01^{\mathrm{X}}$ & $\begin{array}{l}0.84 \pm 0.04^{\mathrm{a}, \mathrm{X}} \\
0.68 \pm 0.02^{\mathrm{b}, \mathrm{X}}\end{array}$ & $\begin{array}{l}0.57 \pm 0.02^{\mathrm{a}, \mathrm{Y}} \\
0.62 \pm 0.06^{\mathrm{a}, \mathrm{X}}\end{array}$ & $\begin{array}{l}0.91 \pm 0.06^{\mathrm{a}, \mathrm{X}} \\
0.75 \pm 0.08^{\mathrm{b}, \mathrm{Y}}\end{array}$ & $\begin{array}{l}0.66 \pm 0.01^{\mathrm{b}, \mathrm{Y}} \\
0.90 \pm 0.02^{\mathrm{a}, \mathrm{X}}\end{array}$ \\
\hline FFA & $\begin{array}{l}\text { Control } \\
\text { OLE }\end{array}$ & $3.73 \pm 0.05^{\mathrm{Y}}$ & $11.54 \pm 0.15^{\mathrm{X}}$ & $\begin{array}{l}6.55 \pm 0.30^{\mathrm{a}, \mathrm{Y}} \\
6.40 \pm 0.46^{\mathrm{a}, \mathrm{Y}}\end{array}$ & $\begin{array}{l}9.47 \pm 0.83^{\mathrm{a}, \mathrm{X}} \\
7.99 \pm 0.53^{\mathrm{b}, \mathrm{X}}\end{array}$ & $\begin{array}{l}7.80 \pm 0.17^{\mathrm{a}, \mathrm{Y}} \\
6.11 \pm 0.05^{\mathrm{b}, \mathrm{Y}}\end{array}$ & $\begin{array}{l}18.83 \pm 0.90^{\mathrm{a}, \mathrm{X}} \\
17.14 \pm 0.19^{\mathrm{b}, \mathrm{X}}\end{array}$ \\
\hline
\end{tabular}

Values are expressed as means $\pm \mathrm{SD},(\mathrm{n}=3), \mathrm{W}$ : white muscle, D: dark muscle.

a,b Different lowercase letters in the same column indicate significant differences $(\mathrm{P}<0.05)$ between samples in the same muscle.

$\mathrm{X}, \mathrm{Y}$ Different capital letters in the same row indicate significant difference $(\mathrm{P}<0.05)$ between two muscles in the same sample.

Table 1. Effect of OLE on $\mathrm{pH}$, TVB-N (mg/100g of sample), PV (mEq/kg of fat), TBA (mg malonaldehyde/kg of the sample) and FFA (oleic acid \%) in white and dark muscles of vacuum-packed frigate mackerel stored at a refrigerated temperature $\left(3 \pm 1^{\circ} \mathrm{C}\right)$. (continued).

\begin{tabular}{|c|c|c|c|c|c|c|c|}
\hline \multicolumn{2}{|c|}{ Storage time (days) } & \multicolumn{2}{|l|}{12} & \multicolumn{2}{|l|}{15} & \multicolumn{2}{|l|}{18} \\
\hline Parameters & Samples & $\mathbf{W}$ & D & $\mathbf{W}$ & D & $\mathbf{W}$ & D \\
\hline pH & $\begin{array}{l}\text { Control } \\
\text { OLE }\end{array}$ & $\begin{array}{l}5.87 \pm 0.02^{\mathrm{a}, \mathrm{Y}} \\
5.73 \pm 0.07^{\mathrm{b}, \mathrm{Y}}\end{array}$ & $\begin{array}{l}5.93 \pm 0.02^{\mathrm{a}, \mathrm{X}} \\
5.88 \pm 0.05^{\mathrm{a}, \mathrm{X}}\end{array}$ & $\begin{array}{l}5.88 \pm 0.02^{\mathrm{a}, \mathrm{X}} \\
5.83 \pm 0.01^{\mathrm{b}, \mathrm{Y}}\end{array}$ & $\begin{array}{l}5.92 \pm 0.02^{\mathrm{a}, \mathrm{X}} \\
5.89 \pm 0.03^{\mathrm{b}, \mathrm{X}}\end{array}$ & $\begin{array}{l}5.76 \pm 0.02^{\mathrm{b}, \mathrm{Y}} \\
5.80 \pm 0.03^{\mathrm{a}, \mathrm{X}}\end{array}$ & $\begin{array}{l}5.82 \pm 0.02^{\mathrm{a}, \mathrm{X}} \\
5.81 \pm 0.02^{\mathrm{a}, \mathrm{X}}\end{array}$ \\
\hline TVB-N & $\begin{array}{l}\text { Control } \\
\text { OLE }\end{array}$ & $\begin{array}{l}19.59 \pm 0.04^{\mathrm{a}, \mathrm{X}} \\
18.43 \pm 0.63^{\mathrm{b}, \mathrm{X}}\end{array}$ & $\begin{array}{l}19.25 \pm 0.20^{\mathrm{a}, \mathrm{Y}} \\
17.97 \pm 0.67^{\mathrm{b}, \mathrm{X}}\end{array}$ & $\begin{array}{l}30.65 \pm 0.07^{\mathrm{a}, \mathrm{X}} \\
28.03 \pm 0.65^{\mathrm{b}, \mathrm{X}}\end{array}$ & $\begin{array}{l}30.11 \pm 0.28^{\mathrm{a}, \mathrm{Y}} \\
27.38 \pm 1.14^{\mathrm{b}, \mathrm{X}}\end{array}$ & $\begin{array}{l}26.80 \pm 0.71^{\mathrm{a}, \mathrm{Y}} \\
20.76 \pm 0.77^{\mathrm{b}, \mathrm{X}}\end{array}$ & $\begin{array}{l}29.31 \pm 0.52^{\mathrm{a}, \mathrm{X}} \\
20.71 \pm 0.90^{\mathrm{b}, \mathrm{X}}\end{array}$ \\
\hline PV & $\begin{array}{l}\text { Control } \\
\text { OLE }\end{array}$ & $\begin{array}{l}3.23 \pm 0.26^{\mathrm{a}, \mathrm{X}} \\
1.77 \pm 0.31^{\mathrm{b}, \mathrm{X}}\end{array}$ & $\begin{array}{l}1.62 \pm 0.01^{\mathrm{a}, \mathrm{Y}} \\
1.35 \pm 0.05^{\mathrm{b}, \mathrm{Y}}\end{array}$ & $\begin{array}{l}4.37 \pm 0.99^{\mathrm{a}, \mathrm{X}} \\
4.18 \pm 0.50^{\mathrm{a}, \mathrm{X}}\end{array}$ & $\begin{array}{l}5.32 \pm 0.25^{\mathrm{a}, \mathrm{X}} \\
1.90 \pm 0.15^{\mathrm{b}, \mathrm{Y}}\end{array}$ & $\begin{array}{l}5.27 \pm 0.65^{\mathrm{a}, \mathrm{X}} \\
1.37 \pm 0.07^{\mathrm{b}, \mathrm{Y}}\end{array}$ & $\begin{array}{l}2.16 \pm 0.04^{\mathrm{a}, \mathrm{Y}} \\
2.41 \pm 0.25^{\mathrm{a}, \mathrm{X}}\end{array}$ \\
\hline TBA & $\begin{array}{l}\text { Control } \\
\text { OLE }\end{array}$ & $\begin{array}{l}1.46 \pm 0.01^{\mathrm{a}, \mathrm{X}} \\
1.34 \pm 0.02^{\mathrm{b}, \mathrm{X}}\end{array}$ & $\begin{array}{l}1.12 \pm 0.01^{\mathrm{a}, \mathrm{Y}} \\
0.99 \pm 0.01^{\mathrm{b}, \mathrm{Y}}\end{array}$ & $\begin{array}{l}0.89 \pm 0.01^{\mathrm{a}, \mathrm{X}} \\
0.67 \pm 0.01^{\mathrm{b}, \mathrm{X}}\end{array}$ & $\begin{array}{l}0.63 \pm 0.02^{\mathrm{a}, \mathrm{Y}} \\
0.60 \pm 0.01^{\mathrm{b}, \mathrm{Y}}\end{array}$ & $\begin{array}{l}1.28 \pm 0.02^{\mathrm{a}, \mathrm{X}} \\
1.17 \pm 0.01^{\mathrm{b}, \mathrm{X}}\end{array}$ & $\begin{array}{l}1.31 \pm 0.01^{\mathrm{a}, \mathrm{X}} \\
0.95 \pm 0.02^{\mathrm{b}, \mathrm{Y}}\end{array}$ \\
\hline FFA & $\begin{array}{l}\text { Control } \\
\text { OLE }\end{array}$ & $\begin{array}{l}8.28 \pm 0.24^{\mathrm{a}, \mathrm{Y}} \\
7.16 \pm 0.18^{\mathrm{b}, \mathrm{Y}}\end{array}$ & $\begin{array}{l}15.65 \pm 0.83^{\mathrm{a}, \mathrm{X}} \\
14.06 \pm 0.36^{\mathrm{b}, \mathrm{X}}\end{array}$ & $\begin{array}{l}8.42 \pm 0.03^{\mathrm{a}, \mathrm{Y}} \\
8.27 \pm 0.14^{\mathrm{a}, \mathrm{Y}}\end{array}$ & $\begin{array}{l}18.25 \pm 0.06^{\mathrm{a}, \mathrm{X}} \\
14.32 \pm 0.09^{\mathrm{b}, \mathrm{X}}\end{array}$ & $\begin{array}{l}10.30 \pm 0.04^{\mathrm{a}, \mathrm{Y}} \\
7.78 \pm 0.20^{\mathrm{b}, \mathrm{Y}}\end{array}$ & $\begin{array}{l}20.53 \pm 0.37^{\mathrm{a}, \mathrm{X}} \\
15.99 \pm 0.13^{\mathrm{b}, \mathrm{X}}\end{array}$ \\
\hline
\end{tabular}

Values are expressed as means $\pm \mathrm{SD},(\mathrm{n}=3), \mathrm{W}$ : white muscle, $\mathrm{D}$ : dark muscle.

a,b Different lowercase letters in the same column indicate significant differences $(P<0.05)$ between samples in the same muscle.

$\mathrm{X}, \mathrm{Y}$ Different capital letters in the same row indicate significant difference $(\mathrm{P}<0.05)$ between two muscles in the same sample.

Peroxide value (PV) characterizes the level of primary lipid peroxidation products. As indicated in Table 1, PV was significantly higher $(\mathrm{p}<0.05)$ in white muscle than dark muscle during all storage period. These results did not concord with those reported by Sohn 
and Ohshima (2010) and this may probably be due to the use of intact fillet with skin. PV did not exceed the pre-established limit of $20 \mathrm{mEq}$ $\mathrm{O} 2 / \mathrm{kg}$ of fat in all packaged samples. This may be attributed to the use of VP that involved complete removal of oxygen with hermetic sealing and led to a significant reduction in lipid peroxidation during the storage (Johnson and Decker, 2015). At the earlier stage, the combination of plant extracts and VP reduced peroxide formation. Throughout the experiment, PV was lower $(\mathrm{p}<0.05)$ in the treated groups than control, and remarkably less in the dark muscles suggesting that the combined application of plant extract and VP effectively delayed the lipid peroxidation in both muscles. However, on day 4, PV of only white muscles rose substantially in the treated sample and was significantly higher $(\mathrm{p}<0.05)$ than the control exhibiting a pro-oxidant effect, rather than an antioxidant. This may be ascribed either to the use of lower concentrations of the extract or to the catalytic effect of chlorophyll and their derivatives that promote lipid peroxidation during storage (Jukic et al., 2015). Alternatively, no differences $(\mathrm{p}>0.05)$ were observed in PV among the dark muscle for all samples until 8 days of the storage. The observed stability in dark muscle may be related to the use of intact fillet. From these observations, it can be concluded that the major effect on reducing peroxide values is attributed to the use of VP. The application of OLE seemed to initiate lipid peroxidation only in white muscle at the early stage of storage.

TBA is a measure of malonaldehyde (MDA) content, which is a secondary end product of lipid hydroperoxide breakdown. In the present study, higher initial TBA values were observed in dark muscle than white muscle (Table 1), which might be due to the higher lipid content in dark muscles. However, Liu et al. (2014) reported a lower TBA values in white and dark muscles of skipjack tuna. In our study, MDA-content white muscles were significantly higher $(\mathrm{p}<0.05)$ than dark muscles after 4 days of storage suggesting that the rate of hydroperoxide decomposition was relatively faster in white muscle throughout the storage period. This could be attributed to the refrigerated condition, to the removal of oxygen and to the use of intact fillet. In the present study, TBA values of all the samples showed a trend to an increase in both muscle types during the storage, followed by a subsequent decline, which was not stable for the later stage of storage. The increase in MDA-content indicated the formation of secondary lipid oxidation products, whereas the decrease in the values may be indicative of an interaction between MDA and proteins, amino acids, glycogen, etc. (Kolakowska, 2002). Irrespective of the sampling day, for both the muscle types, a higher TBA value $(\mathrm{p}<0.05)$ was recorded in controls as compared to the treated samples. On the other hand, a reverse of this was observed between samples on day 8 only for dark muscle and apparently led to TBA formation at the earlier stage of storage. A TBA value of $1-2 \mathrm{mg} \mathrm{MDA} / \mathrm{kg}$ of fish flesh is considered as the threshold limit beyond which fish normally develop an unpleasant flavor (Connell, 1990). In both treated muscles, TBAvalues exceeded $1 \mathrm{mg} \mathrm{MDA} / \mathrm{kg}$ at day 12 of storage; however, MDA-content in both muscles from these samples did not comply with the sensory assessment. Throughout the storage period and especially on day 12 , panelists did not detect any foul odor or taste in the treated samples, probably since TBA values did not exceed the minimum detectable level by tasters, which is estimated at $1.44 \mathrm{mg} \mathrm{MDA} / \mathrm{kg}$ (Ruiz-Capillas and Moral, 2001).

The main objective of using natural extract is to delay the onset of lipid oxidation and oxidative product accumulation. However, it is essential to understand that the muscle type, oxygen availability, and plant extract application, as well as other factors that can affect fat content in fish, may also have an impact on the variation in TBA-content in fishery products and therefore must be taken into consideration during storage. On the basis of TBA data, it can be concluded that the application of OLE $(0.5 \%)$ exhibited an 
antioxidant effect on frigate mackerel muscles. However, further investigations must be carried out to elucidate the mechanism by which the OLE derivatives delay the lipid oxidation.

FFA is an index of hydrolytic activity. Throughout the experiment, regardless of the treatments, there were recorded significant differences $(p<0.05)$ in FFA values between white and dark muscles (Table 1). Lipid hydrolysis was relatively faster in dark muscles than the white muscles. This might be attributed to the higher lipid content and lipase activity present in dark muscle (George and Bokdawala, 1964). In this study, FFA increased with storage time, and the loss of freshness related to hydrolytic activity might occur because of the lipase and phospholipase activity (Quitral et al., 2009). However, a noticeable decline, followed by an increase, was observed only in dark muscle at day 4 and 12 , indicating that the rate of loss succeeded in the rate of FFA production. The loss of FFA during storage is probably due to the increased lipid oxidation, to the interaction with proteins and/or it could be related to the growth of some microorganisms that can use the FFA as an energy source (Anderson and Ravesi, 1968). On the other hand, during the storage, lipid hydrolysis in both muscle types was found higher $(p<0.05)$ in control than the treated samples except for white muscles. No differences $(p>0.05)$ in FFA concentrations were found between treatments at 4 and 15 days. This may happen due to the phenolic compounds present in the plant extracts, which inhibit the activity of FFA liberating enzymes. Hence, the combination of OLE with VP effectively delayed the FFA formation in both muscle types.

\subsection{Microbiological assessments}

The changes in microbial growth of the white and dark muscles of frigate mackerel fillets treated with OLE under vacuum packaging at a refrigerated temperature are presented in Table 2.

Table 2. Effect of OLE on the Mesophilic and Psychrophilic bacterial counts in white and dark muscles of vacuum-packed frigate mackerel stored at a refrigerated temperature $\left(3 \pm 1^{\circ} \mathrm{C}\right)$.

\begin{tabular}{|l|l|l|l|l|l|l|l|}
\hline \multicolumn{2}{|l|}{ Storage time (days) } & O & \multicolumn{4}{l|}{} & 8 \\
\hline Bacteria & Samples & W & D & W & D & W & D \\
\hline $\begin{array}{l}\text { Mesophilic aerobic } \\
\text { bacteria (log cfu/g) }\end{array}$ & $\begin{array}{l}\text { Control } \\
\text { OLE }\end{array}$ & $2.59 \pm 0.16^{\mathrm{Y}}$ & $3.31 \pm 0.15^{\mathrm{X}}$ & $\begin{array}{l}3.55 \pm 0.08^{\mathrm{a}, \mathrm{X}} \\
3.51 \pm 0.25^{\mathrm{a}, \mathrm{X}}\end{array}$ & $\begin{array}{l}3.82 \pm 0.20^{\mathrm{a}, \mathrm{X}} \\
3.24 \pm 0.09^{\mathrm{b}, \mathrm{X}}\end{array}$ & $\begin{array}{l}3.89 \pm 0.36^{\mathrm{a}, \mathrm{X}} \\
3.81 \pm 0.13^{\mathrm{a}, \mathrm{X}}\end{array}$ & $\begin{array}{l}4.01 \pm 0.06^{\mathrm{a}, \mathrm{X}} \\
3.94 \pm 0.44^{\mathrm{a}, \mathrm{X}}\end{array}$ \\
\hline $\begin{array}{l}\text { Psychrotrophic } \\
\text { bacteria }(\log \text { cfu/g) }\end{array}$ & $\begin{array}{l}\text { Control } \\
\text { OLE }\end{array}$ & $2.95 \pm 0.06^{\mathrm{X}}$ & $2.86 \pm 0.10^{\mathrm{X}}$ & $3.74 \pm 0.31^{\mathrm{a}, \mathrm{X}}$ & $\begin{array}{l}3.56 \pm 0.32^{\mathrm{a}, \mathrm{X}} \\
3.07 \pm 0.56^{\mathrm{a}, \mathrm{X}}\end{array}$ & $\begin{array}{l}4.12 \pm 0.12^{\mathrm{a}, \mathrm{X}} \\
3.46 \pm 0.15^{\mathrm{b}, \mathrm{X}}\end{array}$ & $\begin{array}{l}3.89 \pm 0.16^{\mathrm{a}, \mathrm{X}} \\
3.45 \pm 0.09^{\mathrm{b}, \mathrm{X}}\end{array}$ \\
\hline
\end{tabular}

Values are expressed as means $\pm \mathrm{SD},(\mathrm{n}=3), \mathrm{W}$ : white muscle, D: dark muscle.

a,b Different lowercase letters in the same column indicate significant differences $(P<0.05)$ between samples in the same muscle.

$\mathrm{X}, \mathrm{Y}$ Different capital letters in the same row indicate significant difference $(P<0.05)$ between two muscles in the same sample

Table 2. Effect of OLE on the Mesophilic and Psychrophilic bacterial counts in white and dark muscles of vacuum-packed frigate mackerel stored at a refrigerated temperature $\left(3 \pm 1^{\circ} \mathrm{C}\right)$ (continued).

\begin{tabular}{|l|l|l|l|l|l|l|l|}
\hline \multicolumn{2}{|l|}{ Storage time (days) } & \multicolumn{1}{l|}{} & $\mathbf{1 5}$ & \multicolumn{1}{l|}{} \\
\hline Bacteria & Samples & W & D & W & D & W & D \\
\hline $\begin{array}{l}\text { Mesophilic aerobic } \\
\text { bacteria (log cfu/g) }\end{array}$ & Control & $5.07 \pm 0.23^{\mathrm{a}, \mathrm{X}}$ & $4.93 \pm 0.13^{\mathrm{a}, \mathrm{X}}$ & $7.05 \pm 0.04^{\mathrm{a}, \mathrm{X}}$ & $6.74 \pm 0.38^{\mathrm{a}, \mathrm{X}}$ & $7.39 \pm 0.17^{\mathrm{a}, \mathrm{X}}$ & $7.62 \pm 0.14^{\mathrm{a}, \mathrm{X}}$ \\
\hline $\begin{array}{l}\text { OLEchrotrophic } \\
\text { bacteria (log cfu/g) }\end{array}$ & Control & $4.63 \pm 0.27^{\mathrm{a}, \mathrm{X}}$ & $4.59 \pm 0.41^{\mathrm{a}, \mathrm{X}}$ & $5.48 \pm 0.22^{\mathrm{b}, \mathrm{X}}$ & $4.87 \pm 0.30^{\mathrm{b}, \mathrm{Y}}$ & $5.87 \pm 0.31^{\mathrm{b}, \mathrm{X}}$ & $5.84 \pm 0.26^{\mathrm{b}, \mathrm{X}}$ \\
\hline
\end{tabular}

Values are expressed as means $\pm \mathrm{SD},(\mathrm{n}=3), \mathrm{W}$ : white muscle, D: dark muscle.

a,b Different lowercase letters in the same column indicate significant differences $(P<0.05)$ between samples in the same muscle.

$\mathrm{X}, \mathrm{Y}$ Different capital letters in the same row indicate significant difference $(P<0.05)$ between two muscles in the same sample 
The initial low microbial loads observed in this study indicated the good quality of the fish. During the storage, microbial load increased significantly $(\mathrm{p}<0.05)$ with time. Statistical analysis showed that both mesophilic and psychrotrophic bacterial loads were not affected by the muscle type in all treatments, even in the control, which may be due to the elimination of oxygen from the package. The effect of OLE on the mesophilic bacterial load could only be determined in both muscles at the later stages (15 and 18 days). However, the growth of psychrotrophic bacteria was faster in the controls than the treated samples only at the early stage of storage (day 4 and 8 ). In the control samples, regardless of the muscle types, both mesophilic and psychrotrophic bacteria loads exceeded $6 \log _{10} \mathrm{CFU} / \mathrm{g}$ at day 15 of storage. On the other hand, both mesophilic and psychrotrophic bacterial loads reached this limit at day 18 in both muscles in the treated groups conferring an extension of 3 days in microbiological shelf-life for samples treated with OLE. This advocates that the treatment with OLE improved the microbiological quality of both muscle types but it was less effective in reducing mesophilic and psychrotrophic bacterial growth, probably due to the low concentration of the extract.

\subsection{Sensory assessments}

Sensory assessment of raw and cooked white and dark muscles of frigate mackerel fillets stored under vacuum-packaging with or without OLE was evaluated throughout the refrigerated storage period. The total demerit points of the white and dark muscle of frigate mackerel fillets are presented in Fig. 1. Initially, sensory score of all batches were zero, indicating the absolute freshness. The demerit points of both muscles increased with storage time and the quality of fish declined. The loss of freshness during storage was recorded higher in both muscles from control sample compared to their treated counterparts. No significant differences $(p>0.05)$ were observed between the white and dark muscles irrespective of the treatment. Considering the sensory score of 8 as the limit of acceptability, the observed shelflife of both muscles of the control group was no longer than 12 days.

Combination with VP enhanced the organoleptic quality of fish. It improved the quality parameters of fillets by 3 more days in white muscle, whereas an extension of 6 days was observed in the dark muscle compared with their control counterparts (total demerit points were 8.11 and 8.36, respectively). Therefore, OLE had a major enhancement in sensory quality of dark muscle and extended the shelf-life of frigate mackerel. Thiansilakul et al. (2011) reported that the use of vacuumpackaging for the storage of Eastern little tuna fillet extended the acceptable appearance for 3 days more than those maintained in air pack condition. Thus, the observed extension in shelf-life of both muscles of frigate mackerel may a result of the cumulative effect of OLE application at $0.5 \%(\mathrm{w} / \mathrm{v})$ and VP during the storage at a refrigerated temperature.A sensory score of the cooked frigate mackerel was also assessed separately in both muscles throughout the 18 days of storage (Fig. 2). On each sampling day, significant differences $(p<0.05)$ were observed between the control and treated batch in each muscle type; however, the differences observed between both muscles for each batch were no significant ( $p>0.05$ ). Based on the limit of acceptability of $>6$, the sensory quality of both muscle types declined in intensity during storage and exceeded this limit at 12 days for control (demerit scores; 5.82 and 5.69 , respectively) and 15 days for treated samples sample (demerit scores; 6.13 and 5.77, respectively). At the rejection time, general acceptability scores of the cooked white muscle of frigate mackerel fillets were in agreement with their corresponding raw samples, while dark muscle showed an additional extension of 3 days compared to their homologous cooked samples. This might occur due to the undesirable flavor acquired by OLE after cooking. These findings indicate that the combination of OLE and VP may prolong the shelf-life of both muscle types of frigate mackerel. 


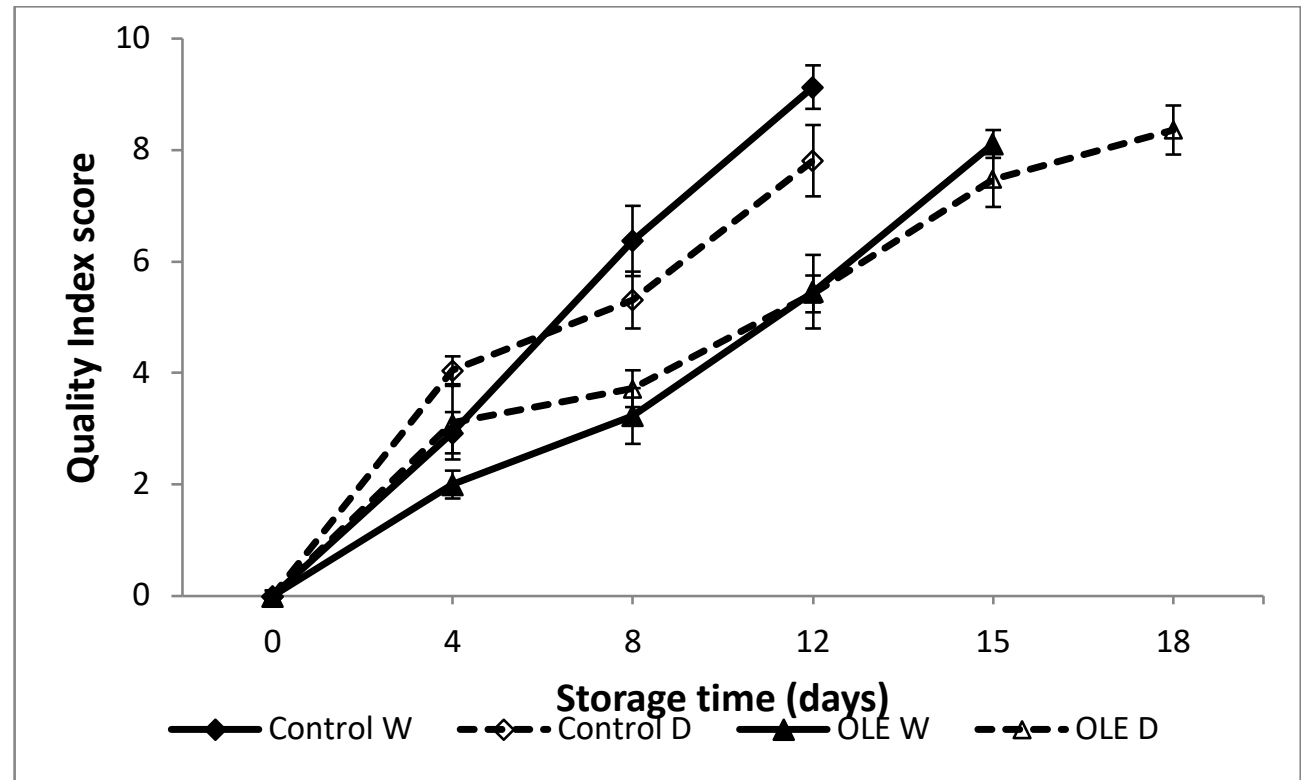

Figure 1. Sensory assessment of the raw white (W) and dark (D) muscles from vacuum-packed frigate mackerel fillets during the storage at a refrigerated temperature: Untreated (Control), Olive leaf extract (OLE). Mean scores of sensory assessment $(n=6)$. Standard deviations are indicated by bars.

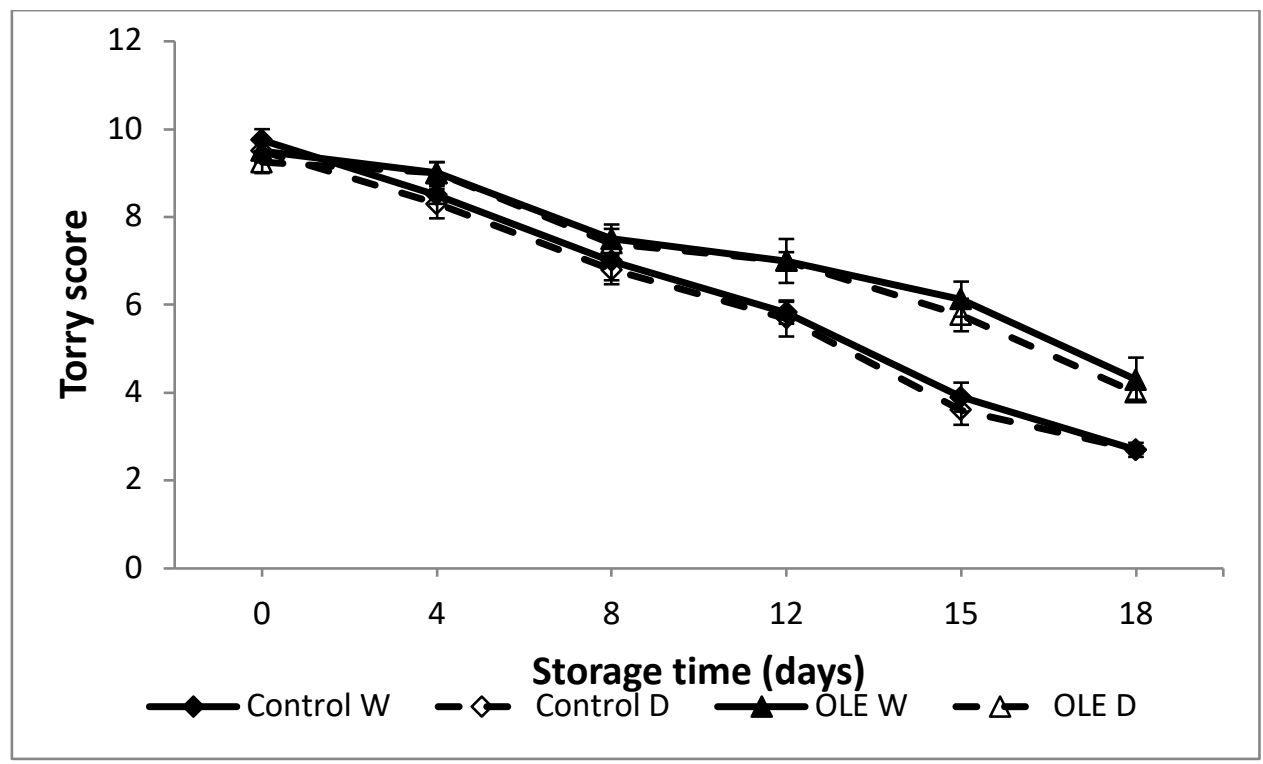

Figure 2. The sensory score of cooked white (W) and dark (D) muscles from vacuum-packed frigate mackerel fillets during the storage at a refrigerated temperature: Untreated (Control), Olive leaf extract (OLE). Mean scores of sensory assessment $(n=6)$. Standard deviations are indicated by bars.

\subsection{Texture Profile Analysis}

TPA results of frigate mackerel fillets during storage are given in Table.3. The hardness (firmness) reduced significantly $(\mathrm{p}<0.05)$ with storage time, indicating that VP alone cannot preserve the hardness of fillet. Initially, both muscles had the same firmness; however, during the experiment, hardness of white muscles became significantly higher $(p<0.05)$ than that of dark muscles. This could be illustrated by the differences in proximate 
composition, enzymatic activities, proteolytic activities and/or the changes in post-mortem $\mathrm{pH}$, which extremely affect the properties of the connective tissue and determine the texture of the muscle (Jinadasa et al., 2015). Both muscles of the treated groups were significantly harder $(\mathrm{p}<0.05)$ than their control counterparts throughout the storage, revealing that the combined use of OLE with VP can prevent the softening of fish muscles.

Table 3. Effect of OLE on texture profile analysis in white and dark muscles of vacuum-packed frigate mackerel stored at a refrigerated temperature $\left(3 \pm 1^{\circ} \mathrm{C}\right)$

\begin{tabular}{|c|c|c|c|c|c|c|c|}
\hline \multicolumn{2}{|c|}{ Storage time (days) } & \multicolumn{2}{|l|}{$\mathbf{0}$} & \multicolumn{2}{|l|}{4} & \multicolumn{2}{|l|}{8} \\
\hline Parameters & Samples & W & D & W & D & $\mathbf{W}$ & D \\
\hline $\begin{array}{l}\text { Hardness } \\
\text { (N) }\end{array}$ & $\begin{array}{l}\text { Control } \\
\text { OLE }\end{array}$ & $45.17 \pm 0.05^{\mathrm{X}}$ & $45.02 \pm 0.11^{\mathrm{X}}$ & $\begin{array}{l}44.49 \pm 0.37^{\mathrm{b}, \mathrm{X}} \\
45.26 \pm 0.01^{\mathrm{a}, \mathrm{X}}\end{array}$ & $\begin{array}{l}43.11 \pm 0.10^{\mathrm{b}, \mathrm{Y}} \\
44.16 \pm 0.04^{\mathrm{a}, \mathrm{Y}}\end{array}$ & $\begin{array}{l}40.08 \pm 0.81^{\mathrm{b}, \mathrm{X}} \\
43.29 \pm 0.24^{\mathrm{a}, \mathrm{X}}\end{array}$ & $\begin{array}{l}38.14 \pm 0.08^{\mathrm{b}, \mathrm{Y}} \\
40.23 \pm 0.16^{\mathrm{a}, \mathrm{Y}}\end{array}$ \\
\hline $\begin{array}{l}\text { Springiness } \\
\text { (Ratio) }\end{array}$ & $\begin{array}{l}\text { Control } \\
\text { OLE }\end{array}$ & $1.90 \pm 0.03^{Y}$ & $1.97 \pm 0.02^{\mathrm{X}}$ & $\begin{array}{l}1.59 \pm 0.03^{\mathrm{b}, \mathrm{Y}} \\
1.78 \pm 0.04^{\mathrm{a}, \mathrm{X}}\end{array}$ & $\begin{array}{l}1.98 \pm 0.01^{\mathrm{a}, \mathrm{X}} \\
1.67 \pm 0.03^{\mathrm{b}, \mathrm{Y}}\end{array}$ & $\begin{array}{l}1.70 \pm 0.02^{\mathrm{a}, \mathrm{X}} \\
1.77 \pm 0.05^{\mathrm{a}, \mathrm{X}}\end{array}$ & $\begin{array}{l}1.70 \pm 0.02^{\mathrm{a}, \mathrm{X}} \\
1.73 \pm 0.01^{\mathrm{a}, \mathrm{X}}\end{array}$ \\
\hline $\begin{array}{l}\text { Adhesiveness } \\
\text { (mJ) }\end{array}$ & $\begin{array}{l}\text { Control } \\
\text { OLE }\end{array}$ & $0.21 \pm 0.03^{Y}$ & $0.43 \pm 0.02^{\mathrm{X}}$ & $\begin{array}{l}0.12 \pm 0.03^{\mathrm{a}, \mathrm{Y}} \\
0.18 \pm 0.03^{\mathrm{a}, \mathrm{Y}}\end{array}$ & $\begin{array}{l}0.31 \pm 0.03^{\mathrm{b}, \mathrm{X}} \\
1.25 \pm 0.02^{\mathrm{a}, \mathrm{X}}\end{array}$ & $\begin{array}{l}0.11 \pm 0.04^{\mathrm{b}, \mathrm{Y}} \\
1.14 \pm 0.05^{\mathrm{a}, \mathrm{X}}\end{array}$ & $\begin{array}{l}1.19 \pm 0.02^{\mathrm{a}, \mathrm{X}} \\
1.24 \pm 0.04^{\mathrm{a}, \mathrm{X}}\end{array}$ \\
\hline $\begin{array}{l}\text { Resilience } \\
\text { (Ratio) }\end{array}$ & $\begin{array}{l}\text { Control } \\
\text { OLE }\end{array}$ & $0.003 \pm 0.001^{\mathrm{X}}$ & $0.001 \pm 0.000^{\mathrm{Y}}$ & $\begin{array}{l}0.005 \pm 0.000^{\mathrm{a}, \mathrm{X}} \\
0.008 \pm 0.003^{\mathrm{a}, \mathrm{X}}\end{array}$ & $\begin{array}{l}0.001 \pm 0.000^{\mathrm{a}, \mathrm{Y}} \\
0.001 \pm 0.000^{\mathrm{a}, \mathrm{Y}}\end{array}$ & $\begin{array}{l}0.010 \pm 0.003^{\mathrm{a}, \mathrm{X}} \\
0.015 \pm 0.003^{\mathrm{a}, \mathrm{X}}\end{array}$ & $\begin{array}{l}0.000 \pm 0.000^{\mathrm{a}, \mathrm{Y}} \\
0.000 \pm 0.000^{\mathrm{a}, \mathrm{Y}}\end{array}$ \\
\hline $\begin{array}{l}\text { Chewiness } \\
\text { (N) }\end{array}$ & $\begin{array}{l}\text { Control } \\
\text { OLE }\end{array}$ & $1.15 \pm 0.04^{\mathrm{X}}$ & $1.07 \pm 0.10^{\mathrm{X}}$ & $\begin{array}{l}0.98 \pm 0.07^{\mathrm{a}, \mathrm{X}} \\
1.10 \pm 0.04^{\mathrm{a}, \mathrm{X}}\end{array}$ & $\begin{array}{l}1.01 \pm 0.01^{\mathrm{a}, \mathrm{X}} \\
1.13 \pm 0.09^{\mathrm{a}, \mathrm{X}}\end{array}$ & $\begin{array}{l}0.91 \pm 0.02^{\mathrm{a}, \mathrm{X}} \\
0.95 \pm 0.02^{\mathrm{a}, \mathrm{X}}\end{array}$ & $\begin{array}{l}0.90 \pm 0.11^{\mathrm{a}, \mathrm{X}} \\
0.93 \pm 0.03^{\mathrm{a}, \mathrm{Y}}\end{array}$ \\
\hline
\end{tabular}

Values are expressed as means $\pm \mathrm{SD},(\mathrm{n}=3), \mathrm{W}$ : white muscle, $\mathrm{D}$ : dark muscle.

a,b Different lowercase letters in the same column indicate significant differences $(P<0.05)$ between samples in the same muscle.

$\mathrm{X}, \mathrm{Y}$ Different capital letters in the same row indicate significant difference $(P<0.05)$ between two muscles in the same sample

Table 3. Effect of OLE on texture profile analysis in white and dark muscles of vacuum-packed frigate mackerel stored at a refrigerated temperature $\left(3 \pm 1{ }^{\circ} \mathrm{C}\right)$. (continued).

\begin{tabular}{|c|c|c|c|c|c|c|c|}
\hline \multicolumn{2}{|c|}{ Storage time (days) } & \multicolumn{2}{|l|}{12} & \multicolumn{2}{|l|}{15} & \multicolumn{2}{|l|}{18} \\
\hline Parameters & Samples & W & D & W & D & $\mathbf{W}$ & D \\
\hline $\begin{array}{l}\text { Hardness } \\
\text { (N) }\end{array}$ & $\begin{array}{l}\text { Control } \\
\text { OLE }\end{array}$ & $\begin{array}{l}38.76 \pm 0.28^{\mathrm{b}, \mathrm{X}} \\
42.78 \pm 0.20^{\mathrm{a}, \mathrm{X}}\end{array}$ & $\begin{array}{l}37.56 \pm 0.50^{\mathrm{b}, \mathrm{Y}} \\
39.72 \pm 0.62^{\mathrm{a}, \mathrm{Y}}\end{array}$ & $\begin{array}{l}35.29 \pm 0.26^{\mathrm{b}, \mathrm{X}} \\
40.97 \pm 0.07^{\mathrm{a}, \mathrm{X}}\end{array}$ & $\begin{array}{l}33.28 \pm 0.14^{\mathrm{b}, \mathrm{Y}} \\
37.12 \pm 0.22^{\mathrm{a}, \mathrm{Y}}\end{array}$ & $\begin{array}{l}30.28 \pm 0.24^{\mathrm{b}, \mathrm{X}} \\
32.60 \pm 0.16^{\mathrm{a}, \mathrm{X}}\end{array}$ & $\begin{array}{l}28.05 \pm 0.21^{\mathrm{b}, \mathrm{Y}} \\
30.11 \pm 0.06^{\mathrm{a}, \mathrm{Y}}\end{array}$ \\
\hline $\begin{array}{l}\text { Springiness } \\
\text { (Ratio) }\end{array}$ & $\begin{array}{l}\text { Control } \\
\text { OLE }\end{array}$ & $\begin{array}{l}1.62 \pm 0.05^{\mathrm{a}, \mathrm{X}} \\
1.70 \pm 0.10^{\mathrm{a}, \mathrm{X}}\end{array}$ & $\begin{array}{l}1.67 \pm 0.02^{\mathrm{a}, \mathrm{X}} \\
1.66 \pm 0.03^{\mathrm{a}, \mathrm{X}}\end{array}$ & $\begin{array}{l}1.53 \pm 0.03^{\mathrm{b}, \mathrm{X}} \\
1.70 \pm 0.01^{\mathrm{a}, \mathrm{X}}\end{array}$ & $\begin{array}{l}1.63 \pm 0.07^{\mathrm{a}, \mathrm{X}} \\
1.66 \pm 0.03^{\mathrm{a}, \mathrm{X}}\end{array}$ & $\begin{array}{l}1.42 \pm 0.04^{\mathrm{b}, \mathrm{Y}} \\
1.52 \pm 0.04^{\mathrm{a}, \mathrm{X}}\end{array}$ & $\begin{array}{l}1.57 \pm 0.02^{\mathrm{a}, \mathrm{X}} \\
1.54 \pm 0.03^{\mathrm{a}, \mathrm{X}}\end{array}$ \\
\hline $\begin{array}{l}\text { Adhesiveness } \\
(\mathrm{mJ})\end{array}$ & $\begin{array}{l}\text { Control } \\
\text { OLE }\end{array}$ & $\begin{array}{l}1.07 \pm 0.05^{\mathrm{a}, \mathrm{X}} \\
1.13 \pm 0.04^{\mathrm{a}, \mathrm{Y}}\end{array}$ & $\begin{array}{l}1.13 \pm 0.04^{\mathrm{b}, \mathrm{X}} \\
1.21 \pm 0.02^{\mathrm{a}, \mathrm{X}}\end{array}$ & $\begin{array}{l}1.03 \pm 0.05^{\mathrm{b}, \mathrm{X}} \\
1.16 \pm 0.03^{\mathrm{a}, \mathrm{X}}\end{array}$ & $\begin{array}{l}1.07 \pm 0.02^{\mathrm{b}, \mathrm{X}} \\
1.22 \pm 0.03^{\mathrm{a}, \mathrm{X}}\end{array}$ & $\begin{array}{l}0.90 \pm 0.10^{\mathrm{a}, \mathrm{X}} \\
1.10 \pm 0.01^{\mathrm{b}, \mathrm{Y}}\end{array}$ & $\begin{array}{l}1.05 \pm 0.04^{\mathrm{a}, \mathrm{X}} \\
1.14 \pm 0.03^{\mathrm{b}, \mathrm{X}}\end{array}$ \\
\hline $\begin{array}{l}\text { Resilience } \\
\text { (Ratio) }\end{array}$ & $\begin{array}{l}\text { Control } \\
\text { OLE }\end{array}$ & $\begin{array}{l}0.001 \pm 0.001^{\mathrm{a}, \mathrm{X}} \\
0.004 \pm 0.003^{\mathrm{a}, \mathrm{X}}\end{array}$ & $\begin{array}{l}0.001 \pm 0.000^{\mathrm{a}, \mathrm{X}} \\
0.001 \pm 0.001^{\mathrm{a}, \mathrm{X}}\end{array}$ & $\begin{array}{l}0.002 \pm 0.001^{\mathrm{a}, \mathrm{X}} \\
0.006 \pm 0.003^{\mathrm{a}, \mathrm{X}}\end{array}$ & $\begin{array}{l}0.000 \pm 0.000^{\mathrm{a}, \mathrm{Y}} \\
0.001 \pm 0.001^{\mathrm{a}, \mathrm{Y}}\end{array}$ & $\begin{array}{l}0.003 \pm 0.002^{\mathrm{a}, \mathrm{X}} \\
0.002 \pm 0.001^{\mathrm{a}, \mathrm{X}}\end{array}$ & $\begin{array}{l}0.000 \pm 0.000^{\mathrm{a}, \mathrm{Y}} \\
0.000 \pm 0.000^{\mathrm{a}, \mathrm{Y}}\end{array}$ \\
\hline $\begin{array}{l}\text { Chewiness } \\
\text { (N) }\end{array}$ & $\begin{array}{l}\text { Control } \\
\text { OLE }\end{array}$ & $\begin{array}{l}0.80 \pm 0.01^{\mathrm{a}, \mathrm{X}} \\
0.84 \pm 0.03^{\mathrm{a}, \mathrm{X}}\end{array}$ & $\begin{array}{l}0.73 \pm 0.06^{\mathrm{a}, \mathrm{X}} \\
0.78 \pm 0.07^{\mathrm{a}, \mathrm{X}}\end{array}$ & $\begin{array}{l}0.75 \pm 0.13^{\mathrm{a}, \mathrm{X}} \\
0.81 \pm 0.09^{\mathrm{a}, \mathrm{X}}\end{array}$ & $\begin{array}{l}0.64 \pm 0.02^{\mathrm{a}, \mathrm{X}} \\
0.73 \pm 0.05^{\mathrm{a}, \mathrm{X}}\end{array}$ & $\begin{array}{l}0.62 \pm 0.03^{\mathrm{a}, \mathrm{X}} \\
0.63 \pm 0.04^{\mathrm{a}, \mathrm{X}}\end{array}$ & $\begin{array}{l}0.56 \pm 0.04^{\mathrm{a}, \mathrm{X}} \\
0.59 \pm 0.05^{\mathrm{a}, \mathrm{X}}\end{array}$ \\
\hline
\end{tabular}

Values are expressed as means $\pm \mathrm{SD},(\mathrm{n}=3)$, W: white muscle, $\mathrm{D}$ : dark muscle.

a,b Different lowercase letters in the same column indicate significant differences $(P<0.05)$ between samples in the same muscle.

$\mathrm{X}, \mathrm{Y}$ Different capital letters in the same row indicate significant difference $(P<0.05)$ between two muscles in the same sample

Springiness is an important characteristic of fish muscles. Initially, the springiness value of dark muscles was significantly higher $(\mathrm{p}<0.05)$ than the white muscles. It decreased in all samples during storage; however, no significant differences $(p>0.05)$ were observed in the muscles. Regarding the individual muscle type, the differences in the springiness values were not significant $(\mathrm{p}>0.05)$ between the treatments, except at day 4, 15 and 18 where springiness 
values of white muscle from the treated group were significantly higher $(\mathrm{p}<0.05)$ than control. These findings confirm that OLE mainly improves the springiness of white muscles only.

Adhesiveness of both dark and white muscles from control groups was significantly $(p<0.05)$ reduced until day 4 and of storage, respectively, followed by a sharp increase on the next sampling day. The similar tendency was also observed for both muscles in the treated group. The increase in adhesiveness might be due to the microbial growth resulting in protein degradation (Lopez-Caballero et al., 2005). Significant differences $(p<0.05)$ in adhesiveness were witnessed between the treatments in both muscles, and it was significantly higher $(\mathrm{p}<0.05)$ than their corresponding controls. In the control samples, the adhesiveness of dark muscles was significantly higher $(p<0.05)$ than that of white muscle at the early stage of storage (until day 8 ). For the remaining storage period, no significant differences $(\mathrm{p}>0.05)$ were observed between both muscle types. However, for the treated groups, dark muscles had significantly higher $(p<0.05)$ adhesiveness than white muscles only on day 4,12 , and 18 of storage. The final values of adhesiveness were largely superior to the initial ones. Thus, the OLE and VP combination seemingly improved the adhesiveness of frigate mackerel muscles.

The elasticity of white muscles given in resilience was significantly higher $(p<0.05)$ than the dark muscles throughout the investigation. Irrespective of muscle type, the changes in the resilience over a period of time were not significant $(p>0.05)$ between both treatments. Thus, the application of OLE along with VP had no major effect on the resilience of both muscles.

Chewiness was also affected in all samples and diminished during the storage. No significant changes $(p>0.05)$ were observed in the chewiness between both muscle types throughout the study. The treatment had no statistically marked effect on chewiness of the muscles, showing that the combined application of OLE and VP did not improve the chewiness of the muscles.

Consequently, the combined application of OLE and VP improved the textural attributes of both frigate mackerel muscles by affecting only the hardness, springiness, and adhesiveness.

\section{Conclusions}

The sensory data revealed that the shelf-life of both frigate mackerel muscles was found to be 12 days for the control samples, while OLE extended the shelf-life of frigate mackerel fillets by 3 and 6 days in white and dark muscles, respectively. The application of $0.5 \%$ OLE with VP apparently initiated the lipid oxidation at the earlier stage of storage and was less effective in reducing microbial growth in both muscles. However, the combined application of OLE and VP improved the texture parameters and exhibited the major impact only on hardness, adhesiveness, and springiness of both frigate mackerel muscles. Therefore, in order to make this system commercially viable, further research work is needed by employing different strategies such as the improvement of a plant extraction method for the recovery of more phenolic compounds, direct application of the extract on fresh seafood products or exploring other extracts with higher lipid solubility.

\section{References}

Anderson, M., Ravesi, E. (1968). Relation between protein extractability and free fatty acid production in cod muscle aged in ice. Journal of the Fisheries Research Board of Canada, 25(10), 2059-2069.

Antonocopoulos, N. (1973). Bestmmung des Flüchtigen Basensticktoofs. In W. Ludorf \& V. Meyer (Eds.), Fische und Fischerzeugnisse (pp. 224-225). Berlin: Aulage Verlag Paul Prey [In German].

AOCS (1994). The official methods and recommended practices of the American Oil Chemists'. Champaign, IL: Journal of American Oil Chemists' Society, pp. Ca 5a40, Cd 8-53.

Ariyawansa, K., Wijendra, D., Senadheera, S. (2003). Quality Index Method developed 
for Frigate tuna (Auxis thazard). Sri Lanka Journal of Aquatic Sciences, 8(1), 95-109.

Benavente-García, O., Castillo, J., Lorente, J., Ortuño, A., Del Rio, J., (2000). Antioxidant activity of phenolics extracted from Olea europaea L. leaves. Food Chemistry, 68(4), 457-62,

Burt, S. (2004). Essential oils: Their antibacterial properties and potential applications in foods-A review. International Journal of Food Microbiology, 94(3), 223-53.

Chaijan, M., Klomklao, S., Benjakul, S. (2013). Characterisation of muscles from Frigate mackerel (Auxis thazard) and catfish (Clarias macrocephalus). Food Chemistry, 139(1-4), 414-19.

Chaves, L. C, Serio, A., Montalvo, . C., Ramirez, C., Peréz Álvarez, J. A., Paparella, A., Mas-trocola, D., \& Martuscelli, M. (2017). Effect of nisin on biogenic amines and shelf life of vacuum packaged rainbow trout (Oncorhynchus mykiss) fillets. Journal of Food Science and Technology, 54(10), 3268-77.

Coma, V. (2008). Bioactive packaging technologies for extended shelf life of meatbased products. Meat Science, 78(1-2), 90103.

Connell, J. J. (1990). Methods of assessing and selecting for quality. In Control of fish quality (3rd ed.), Fishing News Books: Oxford. p 122-150.

Delgado-Adámez, J., Bote, E., Parra-Testal, V., Martín, M., Ramírez, R. (2016). Effect of the olive leaf extracts in vitro and in active packaging of sliced Iberian Pork Far. Packaging technology and science, 29 (12), 649-60.

El-Sohaimy, S. A., Mohamed, G. S., Hagar, S. A., El-Menshawy, H. (2019). Extend Shelflife of Vacuum-Packaged Herring Fish Fillets using Garlic and Ginger Extracts. Journal of Pure and Applied Microbiology, 13(3), 1571-81.

George, J. C. Bokdawala F. D. (1964). Cellular organization and fat utilization in fish muscle. Journal of Animal Morphology and Physiology, 11, 124-32.
Houicher, A., Kuley. E., Bendeddouche. B., Ozogul. F. (2013). Effect of Mentha spicata L. and Artemisia campestris extracts on the shelf life and quality of vacuum packed refrigerated sardine (Sarda pilchardus) fillets. Journal of food Protection, 76, 1719-25.

ISO. (2017) Microbiology of the food chain Preparation of test samples, initial suspension and decimal dilutions for microbiological examination - Part 3: Specific rules for the preparation of fish and fishery products. ISO NORM 6887-3: 2017. International Organization for Standardization ed., Geneva, Switzerland, $16 \mathrm{p}$.

ISO. (2013) Microbiology of the food chain Horizontal method for the enumeration of microorganisms - Part 2: Colony count at $30^{\circ} \mathrm{C}$ by the surface plating technique. ISO Norm 4833-2:2013. International Organization for Standardization ed., Geneva, Switzerland, 12 p.

ISO. (2001) Microbiology of food and animal feeding stuffs - Horizontal method for the enumeration of Psychrotrophic microorganisms. ISO Norm 17410:2001. International Organization for Standardization ed., Geneva, Switzerland, 8 p.

Jeyasekaran, G., Ganesan, P., Anandaraj, R., Jeya Shakila, R., Sukumar, D. (2006). Quantitative and qualitative studies on the bacteriological quality of Indian white shrimp (Penaeus indicus) stored in dry ice. Food Microbiology, 23(6), 526-33.

Johnson, D., Decker, E. (2015). The role of oxygen in lipid oxidation reactions: A review. Annual Review of Food Science and Technology, 6(1), 171-90.

Jinadasa, B., Galhena, C. Liyanage, N. (2015). Histamine formation and the freshness of yellowfin tuna (Thunnus albacares) stored at different temperatures. Cogent Food \& Agriculture, 1(1),

Junsi, M., Usawakesmanee, W., Siripongvutikorn, S. (2012). Effect of using starch on off-odors retention in tuna dark 
meat. International Food Research Journal, 19(2), 709-14.

Jukic, H., Habes, S., Aldzic, A., Durgo, K., Kosalec, I. (2015). Antioxidant and prooxidant activities of phenolic compounds of the extracts of Echinacea purpurea (L.). Bulletin of the chemists and technologists of Bosnia and Herzegovina, 44, 43-52.

Kenar, M., Özogul, F., Kuley, E. (2010). Effects of rosemary and sage tea extracts on the sensory, chemical and microbiological changes of vacuum-packed and refrigerated sardine (Sardina pilchardus) fillets. International Journal of Food Science \& Technology, 45(11), 2366-72.

Kolakowska, A. (2002). Lipid oxidation in food systems. In Sikorski, Z.E. and Kolakowska A. (Eds.). Chemical and Functional Properties of Food Lipids, (pp. 133-165), London, UK: CRC Press.

Krízek, M., Vacha, F., Vorlova, L., Lukasova, J., Cupakova, S. (2004). Biogenic amines in vacuum-packed and non-vacuum-packed flesh of carp (Cyprinus carpio) stored at different temperatures. Food Chemistry, 88(2), 185-91.

Lahreche, T., Uçar, Y., Kosker, A. R., Hamdi, T. M., Ozogul, F. (2019). Combined impacts of oregano extract and vacuum packaging on the quality changes of frigate tuna muscles stored at $3 \pm 1{ }^{\circ} \mathrm{C}$. Veterinary World, 12(1): 155-64.

Li, Q., Li, D., Qin, N., Hong, H., Luo, Y. (2016). Comparative studies of quality changes in white and dark muscles from common carp (Cyprinus carpio) during refrigerated $\left(4^{\circ} \mathrm{C}\right)$ storage. International Journal of Food Science \& Technology, 51(5), 1130-39.

Liu, S., Li, X., Zhou, X., Zhang, X., Ding, Y. (2014). Comparative study of basic characteristics of ordinary and dark muscle in skipjack tuna (Katsuwonus pelamis). Food Science and Biotechnology, 23(5), 1397-404.

Lopez-Caballero, M., Goamez-Guillen, M., Perez-Mateos, M., Montero, E. (2005). A functional chitosan-enriched fish sausage treated by high pressure. Journal of Food Science, 70(3), 166-71.

Mazorra-Manzano, M., Pacheco-Aguilar, R., Diaz-Rojas, E., Lugo-Sanchez, M. (2000). Postmortem changes in black skipjack muscle during storage in ice. Journal of Food Science, 65(5), 774-79.

Modigh, M., Tota, B. (1975). Mitochondrial respiration in the ventricular myocardium and in the white and deep red myotomal muscles of juvenile tuna fish (Thunnus thynnus L.). Acta Physiologica Scandinavica, 93(3), 289-94.

Putro, S. (1989). Dry ice-possible uses in fresh and live fish handling. Infofish International, 4, 24-25.

Quitral, V., Donoso, M., Ortiz, J., Herrera, M., Araya, H., Aubourg, S. (2009). Chemical changes during the chilled storage of Chilean jack mackerel (Trachurus murphyi): Effect of a plant-extract icing system. LWT - Food Science and Technology, 42(8), 1450-4.

Ruiz-Capillas, C., \& Moral, A. (2005). Sensory and biochemical aspects of quality of whole bigeye tuna (Thunnus obesus) during bulk storage in controlled atmospheres. Food Chemistry, 89(3), 347-54.

Ruiz-Capillas, C., Moral, A. (2001). Residual effect of $\mathrm{CO}_{2}$ on hake (Merluccius merluccius L.) stored in modified and controlled atmospheres. European Food Research and Technology, 212(4), 413-20.

Skandamis, P., Nychas, G. (2001). Effect of oregano essential oil on microbiological and physico-chemical attributes of minced meat stored in air and modified atmospheres. Journal of Applied Microbiology, 91(6), 1011-22.

Sohn, J., Ohshima, T. (2010). Control of lipid oxidation and meat color deterioration in skipjack tuna muscle during ice storage. Fisheries Science, 76(4), 703-10.

Song, Y., Liu, L., Shen, H., You, J., Luo, Y. (2011). Effect of sodium alginate-based edible coating containing different antioxidants on quality and shelf life of refrigerated bream (Megalobrama 
amblycephala). Food Control, 22(3-4), 608-15.

Tarladgis, B., Watts, B. M., Younathan, M. (1960). A distillation method for the quantitative determination of malonaldehyde in rancid foods. Journal of the American Oil and Chemists' Society, 37(1), 44-48.

Thiansilakul, Y., Benjakul, S., Richards, M. (2011). The effect of different atmospheric conditions on the changes in myoglobin and colour of refrigerated Eastern little tuna (Euthynnus affinis) muscle. Journal of the Science of Food and Agriculture, 91(6), 1103-10.

Ucak, I., Ozgul, Y., Durmus, M. (2011). The effects of rosemary extract combination with vacuum packing on the quality changes of Atlantic mackerel fish burgers. International Journal of food science and technology, 46, 1157-63.

Viji, P., Panda, S. K., Mohan, C. O., Bindu, J., Ravishankar, C. N., Srinivasa Gopal, T. K. (2016). Combined effects of vacuum packaging and mint extract treatment on the biochemical, sensory and microbial changes of chill stored Indian mackerel. Journal of food science and technology, 53(12), 428997.

Wendakoon, C., Murata, M., Sakaguchi, M. (1990). Comparison of non-volatile amine formation between the dark and white muscles of mackerel during storage. Nippon Suisan Gakkaishi, 56(5), 809-18.

Woyewoda, A. D., Shaw, S. J., Ke, P. J. Burns, B. G. (1986). Recommended Laboratory Methods for Assessment of Fish Quality. Canadian Technical Report of Fisheries and Aquatic Sciences, 1448. Halifax, Canada.

\section{Acknowledgment}

This research did not receive any specific grant and was done in the Biotechnology Laboratory of the Department of Seafood Processing Technology, Faculty of Fisheries, Cukurova University, Adana, Turkey. 